\title{
Immunological Evaluation of Fc Receptor Mediated Antigen Delivery of Brucella melitensis Recombinant Outer Membrane Protein 28 (Romp 28) in Mice
}

\author{
Ramya Kalaivanan ${ }^{1}$, Sankar Palanisamy ${ }^{1}$, Tapas Kumar Goswami², \\ Pallab Chaudhury ${ }^{2}$ and G. C. Ram ${ }^{2}$ \\ ${ }^{1}$ Veterinary College and Research Institute, Namakkal, Tamil Nadu Veterinary and Animal \\ Sciences University, Chennai, India \\ ${ }^{2}$ Indian Veterinary Research Institute, Izatnagar Bareilly, India \\ *Corresponding author
}

\section{A B S T R A C T}

K e y w o r d s
Outer membrane
protein (rOMP 28),
Fc fragment of IgG,
SDS PAGE,
Protection,
Challenge infection
Article Info
Accepted:
18 April 2020
Available Online:
10 May 2020

\section{Keywords} Fc fragment of $\mathrm{IgG}$, SDS PAGE,

Protection,

Challenge infection

Article Info

18 April 2020

10 May 2020
The present study was aimed to prepare a conjugate of $\mathrm{Fc}$ fragment of mice $\mathrm{IgG}$ with rOMP 28 of Brucella melitensis and investigate its ability to influence the kinetics of humoral and cellular immune response in comparison to its unconjugated counterpart and the $r$ OMP 28 alone in the mice model. Among all the groups, the group of mice immunized with $r$ Omp28 alone induced highest level of humoral immune response and the vaccine strain group $(\mathrm{S} 19)$ conferred highest level of cellular response which was evidenced by higher nitric oxide concentration and the clearance of virulent B. abortus 544 from the spleen upon challenge infection. The conjugated group conferred low level of humoral response compared to the $r \mathrm{OMP} 28$ alone which may be due to the involvement of inhibitory Fc $\gamma$ IIR in the regulation of immune responses, soluble forms of Fc $\gamma \mathrm{R}$ inhibiting antigen presentation and irreversible loss of Fc receptors on the macrophage plasma membrane. The S19 strain of B. abortus, a live vaccine conferred high level of protection when challenged with virulent $B$. abortus 544 which indicate whole cell organism composed of various immunogenic components might have been involved in inducing protection.

\section{Introduction}

Brucellosis is an economically significant disease-causing abortion and infertility in infected animals and undulant fever in humans. The disease is caused by Gramnegative, nonmotile, non-spore-forming, partially acid fast, strict aerobe, some strains require carbon dioxide, especially on primary isolation, intracellular coccobacilli or short rods and are oxidase, catalase, nitrate reductase and urease positive (Young et al., 1985). B. abortus, B. melitensis, B. suis and B. canis preferentially infects cattle, sheep and 
goats, pigs and dogs respectively. All the above species infect humans with $B$. melitensis being the most common. Brucella abortus causes abortion and infertility in cattle. Efforts have been made to control this important disease through vaccination with live attenuated $B$. abortus strain 19 and killed strain 45/20. Although these vaccines have been found effective against brucellosis, they have some disadvantages, such as the ability to cause disease in humans, the possibility of causing abortion when administered to pregnant cattle and the diagnostic difficulty of distinguishing field infections from vaccinated animals (Baldi et al., 1996).A vaccine that will be noninfectious and effective in stimulating a broad protective immune response is needed to control brucellosis. With the advent of genetic engineering techniques, it is now possible to generate non-infectious vaccines like subunit and DNA vaccines for economically important disease like brucellosis. One such approach was the production of recombinant proteins from zoonotically important Brucella sp. and its use as vaccine candidate.

Brucella OMPs are divided based on their molecular mass into group 1 antigens with a molecular mass of $94 \mathrm{kDa}$, group 2 antigens of approximately $41-43 \mathrm{kDa}$ and group 3 antigens of $30 \mathrm{kDa}$. Omp28 and Omp25 are both group 3 antigens and are distinct from each other based on molecular mass (Santos et al., 1984). The $28 \mathrm{kDa}$ OMP (OMP28) of B.melitensis belongs to group III antigens. OMP28, also been termed as BP26 and CP28, is an immune dominant antigen localized in the periplasm and this protein has been a target molecule for detection of anti-Brucella antibodies (Lindler et al., 1996; Debbarh et al., 1996; Cloeckaert et al., 2001).

Effective immune response to a diseasecausing agent is highly essential to get rid of the infection. Even though available vaccines are competent to induce desired immune response, glitches during the differential diagnosis of infected and vaccinated animal prompt us to seek alternative strategies. The current study was undertaken for the targeted delivery of the weakly immunogenic subunit vaccine to be conjugated with Fc portion of mice immunoglobulin to immune effector cells like B cells, NK cells, Neutrophils, macrophages etc., through the Fc gamma receptor (FcyR) they possess (Qiu et al., 1990). FcR again acts as a trigger molecule for inflammatory, allergic, cytolytic, endocytic, and phagocytic activities of immune cells (Fridman et al., 1992).So FcR responsible for receptor mediated endocytosis can be targeted to enhance the antigen uptake. Fc receptors responsible for various isotypes of immunoglobulin are located on different types of cells involved in immune response. In this way it is possible to achieve enhanced immune response even with very less available antigen by artificially augmenting antigen uptake by the cells possessing surface receptors. These receptors were also effectively used by the immunologists to target the vaccines to a particular cell to induce high level of immune response without any adjuvant.

In the present study, recombinant outer membrane protein 28 (rOMP 28) of Brucella melitensis was used to study the efficacy of receptor mediated antigen delivery system. The E. coli expressed purified rOMP 28 protein was conjugated with Fc portion of mouse IgG using glutaraldehyde as a crosslinker and the kinetics of immune response was studied in the mice model.

\section{Materials and Methods}

\section{Experimental animals}

Apparently healthy Swiss albino mice of 4-6 weeks age were obtained from the Laboratory 
Animal Resource Section, Indian Veterinary Research Institute, Izatnagar. The animals were housed in cages and provided feed and water ad libitum. The guidelines of Institutional animal ethics committee were followed for maintenance, handling and care of animals.

\section{Biologicals}

Brucella abortus 544 virulent strain and Brucella abortus S-19 live vaccine strain was obtained from the Brucella Referral Lab., Division of Veterinary Public Health, IVRI, Izatnagar. Anti-mouse $\mathrm{IgG}$ and its isotypes (Total IgG, IgG1, IgG2a and IgG2b) HRPO conjugates (Sigma) were used for the assay of immune globulins.

\section{Separation of serum}

Blood was collected from the mice and kept at room temperature undisturbed for 2 hours and overnight at $4^{\circ} \mathrm{C}$. The clotted blood was subjected to centrifugation at $2000 \mathrm{rpm}$ for 10 minutes at $4^{\circ} \mathrm{C}$. Separated serum was collected and pooled together and stored at $-20^{\circ} \mathrm{C}$ for immunoglobulin (IgG) precipitation.

\section{Ammonium sulphate precipitation of Immuno globulins}

Saturated ammonium sulphate solution was prepared in double distilled water and kept in incubator for overnight, clarified by filtration using $0.22 \mu \mathrm{m}$ filter and $\mathrm{pH}$ was adjusted to 7.4. Four $\mathrm{ml}$ of saturated ammonium sulphate solution was added drop wise to about $6 \mathrm{ml}$ of serum with continuous stirring in order to achieve a final concentration of $40 \%(\mathrm{v} / \mathrm{v})$ saturation. The solution was left undisturbed overnight at $4^{\circ} \mathrm{C}$ and centrifuged at $2500 \mathrm{rpm}$ for 10 minutes. The supernatant was discarded and the precipitate thus obtained was redissolved in distilled water to its original volume and reprecipitated with saturated ammonium sulphate solution to final concentration of $40 \%(\mathrm{v} / \mathrm{v})$. The precipitate containing immune globulins (IgG) was collected again by centrifugation and dissolved in Phosphate Buffer Saline (PBS $\mathrm{pH}$ 7.4).

The dissolved precipitate was dialyzed against PBS ( $\mathrm{pH}$ 7.4) in dialysis tubing having a molecular weight cut off $12 \mathrm{kDa}$ with several changes of PBS until free from ammonium sulphate. The presence of ammonium sulphate in the immunoglobulin precipitate was detected by Nessler's reagent.

\section{Purification of immunoglobulin G using protein- A agarose}

About 1ml of Protein A agarose (Sigma) was taken in a syringe column and allowed to settle. Once the column has settled, it was washed with 20 column volumes of Buffer A as per the manufacturer's instruction. The immunoglobulin dialyzed against PBS was then applied to the column and the column was washed with 10 column volumes of buffer A.

The bound IgG was then eluted using 3 column volumes of buffer $\mathrm{B} \mathrm{pH} \mathrm{4.5.} \mathrm{The}$ eluates were neutralized by collecting in $0.1 \mathrm{M}$ $\mathrm{NaOH}$ to prevent denaturation. The different fractions of the eluates were checked for the purity in $12.5 \%$ sodium dodecyl sulfate polyacrylamide gel electrophoresis (SDS PAGE) described by Laemmli (1970). The eluates with pure immune globulins were chosen and pooled for digestion.

\section{Fragmentation of mouse immunoglobulin $G$ with preactivated papain}

The purified IgG was subjected to fragmentation with preactivated papain (Parham et al., 1982). Four mg of papain was dissolved in $2 \mathrm{ml}$ of $0.1 \mathrm{M}$ acetate buffer, $\mathrm{pH}$ 
5.5 containing $0.003 \mathrm{M}$ EDTA and $50 \mathrm{mM}$ cysteine hydrochloride. This solution of papain was incubated at $37^{\circ} \mathrm{C}$ for $30 \mathrm{~min}$ for preactivation. Following incubation, the papain solution was dialyzed against $0.1 \mathrm{M}$ acetate buffer with 0.003M EDTA for $6 \mathrm{hrs}$ in order to remove the cysteine. Papain was preactivated just before starting the digestion. Papain concentration was determined spectrophotometrically against $0.1 \mathrm{M}$ acetate buffer with 0.003M EDTA as blank.

Six $\mathrm{mg}$ of purified mouse $\mathrm{IgG}$ was equilibrated by dialysis against $0.1 \mathrm{M}$ acetate buffer, pH 5.5 with $0.003 \mathrm{M}$ EDTA for overnight. To about $6 \mu \mathrm{g}$ of mouse IgG, 300 $\mu \mathrm{g}$ of preactivated papain was added and incubated in a water bath for $12 \mathrm{hrs}$ at $37^{\circ} \mathrm{C}$ in $0.1 \mathrm{M}$ acetate buffer with $0.003 \mathrm{M}$ EDTA.

After $12 \mathrm{hrs}$ of incubation, the digestion reaction was stopped by addition of iodoacetamide to achieve a final concentration of $30 \mathrm{mM}$. The digested protein samples were dialyzed against PBS ( $\mathrm{pH}$ 7.4) to remove the acetate buffer. The digested products were analyzed by SDS PAGE $(12.5 \%)$ in the absence of beta mercaptoethanol.

\section{Purification of $\mathrm{Fc}$ fragment in protein $\mathrm{A}$ agarose}

The digested products were applied on the column containing Protein A agarose and washed with 10 column volumes of buffer A. Then the bound $\mathrm{Fc}$ fragment was eluted with buffer B (pH 4.5). The eluates were collected and $\mathrm{pH}$ was brought to neutral with $0.1 \mathrm{~N}$ $\mathrm{NaOH}$ immediately to prevent denaturation. The purity of the Protein A agarose purified $\mathrm{Fc}$ fragment was confirmed in SDS PAGE $(12.5 \%)$ under non reducing condition. The concentration of the $\mathrm{Fc}$ fragment was determined spectrophotometrically against buffer B as blank.

\section{Purification of recombinant outer} membrane protein 28 of Brucella melitensis

The E. coli cell having the gene for outer membrane protein 28 of Brucella melitensis in pPROC expression vector was obtained from Dr. Pallab Chaudhuri, Division of Bacteriology was grown in LB medium till the $\mathrm{OD}$ values reached 0.5 at $600 \mathrm{~nm}$. The $E$. coli cells were then induced with $1 \mathrm{mM}$ IPTG and allowed to grow further for $6 \mathrm{~h}$ at $37^{\circ} \mathrm{C}$. The E. coli cells were harvested and the $r$ OMP 28 was purified using Ni-NTA agarose according to the instructions of the manufacturer (Qiagen, USA) and analyzed on SDSPAGE. The concentration of the protein was determined as per the described the method (Lowry et al., 1951) as well as spectrophotometrically at $280 \mathrm{~nm}$.

\section{Conjugation of $r \mathrm{OMP} 28$ with IgG Fc using glutaraldehyde}

Conjugation was done following the protocol described by Baron and Baltimore (1982). Approximately $2.5 \mathrm{mg} \mathrm{Fc}$ fragment was added to $2.5 \mathrm{mg}$ of $r \mathrm{OMP} 28$. The $\mathrm{Fc}$ fragment and $r$ OMP 28 were dialyzed against PBS-pH 7.4 before use. About $0.5 \mathrm{ml}$ of glutaraldehyde solution $(20 \mathrm{mM})$ was added immediately to the mixture drop wise, mixing gently with a magnetic stirrer for one hour at room temperature. After one hour, once the mixture turns milky, the reaction was stopped by adding $100 \mu 1$ of glycine solution $(10 \mathrm{mM}$ final concentration) to inactivate the unreacted glutaraldehyde. Conjugated protein was dialyzed against 4 to 5 liters of PBS, $\mathrm{pH}$ 7.4 for 48 hours at $4^{\circ} \mathrm{C}$ to remove the glutaraldehyde and glycine from conjugate solution. The conjugation was confirmed by resolving in $12.5 \%$ SDS PAGE.

The protein concentration of the conjugate was determined spectrophotometrically at 280nm against PBS as blank. 


\section{Preparation of glutaraldehyde treated OMP 28}

About $3 \mathrm{mg}$ of purified rOMP 28 dialyzed against PBS (pH 7.4) was treated with $20 \mathrm{mM}$ glutaraldehyde for one hour and the reaction was stopped with $10 \mathrm{mM}$ glycine. Glutaraldehyde treated rOMP 28 was dialyzed against 4 litres of PBS ( $\mathrm{pH} 7.4)$ for 48 hrs.

\section{Preparation of $B$. abortus $S 19$ for vaccination and $B$. abortus 544 for challenge study}

The B. abortus $S 19$ and B. abortus 544 were sub cultured separately on tryptose phosphate agar slant. B. abortus $S 19$ slants were incubated at $37^{\circ} \mathrm{C}$ for 48 to $72 \mathrm{~h}$. However, $B$. abortus 544 slant cultures were incubated at $37^{\circ} \mathrm{C}$ under $5 \% \mathrm{CO}_{2}$ tension for 72 to $96 \mathrm{~h}$. The viable bacterial count was determined as per the described method (Alton et al., 1975).Briefly, serial ten-fold dilution $\left(10^{-1}\right.$ to $10^{-10}$ ) of the bacterial suspensions (B. abortus $S 19$ and B. abortus 544 harvested from slants) were made in tryptose phosphate broth. About $20 \mu \mathrm{l}$ from each dilution starting from $10^{-5}$ to $10^{-10}$ was plated on tryptose phosphate agar in triplicate. The plates were incubated at $37^{\circ} \mathrm{C}$ for $48-72 \mathrm{~h}$ for B. abortus $S 19$ and $72-96 \mathrm{~h}$ at $37^{\circ} \mathrm{C}$ in $5 \% \mathrm{CO}_{2}$ tension for B. abortus 544 . Plates showing 30-300 CFU were selected for colony count. The mean of all the plates were multiplied by dilution factor and viable bacteria were counted as colony forming unit (cfu) $/ \mathrm{ml}$. Then $1 \times 10^{5} \mathrm{cfu} / \mathrm{ml}$ of B. abortus $S 19$ was used for intra peritoneal immunization and $1 \times 10^{5} \mathrm{cfu} / \mathrm{ml}$ of $B$. abortus 544 were used for challenge study.

\section{Immunization of mice}

A total of 60 Swiss albino mice of either sex were randomly distributed into six groups and caged separately. All the groups were immunized on day 0,14 and 21 as shown in the Table 1 except the Brucella abortus S19which was given as a single dose.

\section{Assessment of humoral immune response}

\section{Indirect ELISA}

To assess the humoral immune responses blood was collected from the immunized and control groups on day $0,7,14,21$ and 28days post vaccination. The immunoassay plates (Maxisorp, Nunc, Denmark) were coated with purified $r$ OMP28 protein at a concentration of 100 ngper well, diluted in 0.1 Mbicarbonate buffer $(\mathrm{pH} 9.0)$ and incubated overnight at $4^{\circ} \mathrm{C}$. The wells were emptied and washed five times with phosphate buffer saline-Tween20 (PBST) and blocked with PBST containing5\% BSA. Immunoassay plates were charged with sera ata dilution of 1:100 and incubated at $37^{\circ} \mathrm{C}$ for $1 \mathrm{~h}$ and washed five times with PBST. The plates were incubated with respective HRPO conjugates for $1 \mathrm{~h}$ at $37{ }^{\circ} \mathrm{C}$. After washing with PBST, substrate solution containing Ortho-phenyl diamine (OPD) and $\mathrm{H}_{2} \mathrm{O}_{2}$ were added. Color development was stopped by adding $2 \mathrm{M}$ $\mathrm{H}_{2} \mathrm{SO}_{4}$ after incubating the plates for 10 minutes in dark at room temperature. Absorbance/Optical density (OD) values were recorded at490 $\mathrm{nm}$ wavelength in an ELISA reader.

\section{Determination of antigen specific antibodies by western blotting}

The production of antigen specific antibodies in sera of the animals immunized with various antigen preparations were determined by Western blot analysis. The purified rOMP $28(2.5 \mu \mathrm{g})$ was electrophoretically resolved in SDS PAGE (12.5\%) and the resolved proteins were electrophoretically transferred to polyvinyl difluoride (PVDF). 
Semi dry blotting steps were followed as described by Towbin et al., (1979).

\section{Assessment of cell mediated immune response}

\section{Lymphocyte transformation test (LTT)}

Spleens from two immunized mice from each group were taken after 30 and 40 days of first inoculation after sacrifice, splenocytes were collected by repeated perfusion with sterile PBS using insulin syringe. The splenocytes were isolated using Histopaque (1077). To 1.5 $\mathrm{ml}$ of histopaque, $3 \mathrm{ml}$ of splenocyte suspension was over layered and centrifuged at $1600 \mathrm{rpm}$ for $40 \mathrm{~min}$. The interface containing lymphocytes was collected in a fresh tube and two washings were done with sterile PBS and finally resuspended in RPMI 1640 growth medium. The blastogenic response of splenocytes was assessed by MTT colorimetric method as described by Mosmann (1983).

Briefly, $100 \mu 1$ of splenocyte cell suspension $\left(2 \times 10^{6}\right.$ cells $\left./ \mathrm{ml}\right)$ was added to 96-well flat bottom tissue culture plate (Griener). Then $100 \mu 1$ of RPMI-1640 growth medium containing either Con A (for positive control) @ 20 $\mu \mathrm{g} / \mathrm{ml}$ or antigen ( $r \mathrm{OMP} 28$ ) @ $2 \mu \mathrm{g} / \mathrm{ml}$ was added in triplicate wells. For negative control, $100 \mu \mathrm{l}$ of growth medium without antigen or mitogen was added in triplicate wells. The plate was sealed properly with adhesive tape and incubated at $37^{\circ} \mathrm{C}$ in a humidified chamber with $5 \% \mathrm{CO}_{2}$. After 96 hours of incubation, 20 $\mu 1$ of MTT solution (5 $\mathrm{mg} / \mathrm{ml}$ in PBS) was added to each well and further incubated at $37^{\circ} \mathrm{C}$ for $4 \mathrm{hr}$. The plates were then centrifuged at $1,500 \mathrm{rpm}$ for $10 \mathrm{~min}$ and $100 \mu 1$ of culture supernatant was discarded from each well. Finally, $150 \mu$ of dimethyl sulfoxide (DMSO) was added to each well and mixed thoroughly avoiding air bubbles. OD measured at $550 \mathrm{~nm}$.
Stimulation index (SI) was calculated using the following formula:

$$
\mathrm{SI}_{(\mathrm{MTT})}=\frac{\text { Mean OD of stimulated culture }}{\text { Mean OD of unstimulated culture }}
$$

\section{Nitric oxide production assay}

Splenocytes from the immunized groups were isolated as mentioned in the lymphocyte proliferation assay. In this assay, the RPMI 1640 medium (without phenol red) was supplemented with $5 \mathrm{mM} \mathrm{L}$ - arginine. One $\mathrm{ml}$ of cell suspension containing $1 \times 10^{6}$ cells was plated in triplicate in 96 well plates. The splenocytes from different groups were activated with $r \mathrm{OMP} 28 @ 10 \mu \mathrm{g} / \mathrm{ml}$. The plates were incubated at $37^{\circ} \mathrm{C}$ and $5 \% \mathrm{CO}_{2}$ for 2 days. Culture supernatants were collected from all the wells at 24, 30 and $40 \mathrm{hrs}$ intervals. The collected supernatants were stored at $-20^{\circ} \mathrm{C}$ until $\mathrm{NO}$ estimation. For nitric oxide (NO) estimation, different concentrations of $\mathrm{NaNO}_{2}$ (Sodium nitrite)was used for preparing standard curve.

In a 96 well ELISA plate, to $50 \mu 1$ of the cell culture supernatant or standard, $50 \mu \mathrm{l}$ of Griess reagent were added and incubated at $37^{\circ} \mathrm{C}$ for $30 \mathrm{~min}$. Absorbance was measured at $550 \mathrm{~nm}$. The NO level in the sample was extrapolated using the standard curve $\left(\mathrm{NaNO}_{2}\right.$ concentration vs O.D at $550 \mathrm{~nm}$ ).

\section{Protection study by challenge infection}

All the groups of mice were challenged 45 days post primary immunization with $1 \times 10^{5}$ CFU of Brucella abortus Strain 54 in $200 \mu 1$ of sterile PBS intraperitonially. Four weeks after challenge, three mice from each group were sacrificed for splenic clearance assay. Spleen from each mouse was removed, homogenized in $2 \mathrm{ml}$ of TPB (Tryptose Phosphate Broth). 
A tenfold serial dilution was made in TPB and $20 \mu \mathrm{l}$ suspension was plated on Tryptose phosphate agar. B. abortus 544 colonies were counted after incubation for $72-96 \mathrm{~h}$ at $37^{\circ} \mathrm{C}$ under $5 \% \quad \mathrm{CO}_{2}$. The difference of $\log$ organism burdens in spleen of PBS control (unimmunized) mice and the vaccinated groups was considered as protection in terms of splenic clearance.

\section{Statistical analysis}

The results of ELISA and lymphocyte proliferation assay are expressed as mean \pm standard error (SE). In protection studies, log values of total no. of Brucella per spleen of mice were calculated and protection was assessed by subtracting the log colony forming unit of immunize mice from those of PBS control. One-way analysis of variance was used to test the statistical significance by SPSS 11.0. $P$ value less than 0.01 was considered statistically significant as it showed significantly high level of protection as compared to PBS control group.

\section{Results and Discussion}

Precipitation and determination of concentration of mouse immunoglobulin

The serum precipitated with saturated ammonium sulphate solution revealed two thick bands, one about $55 \mathrm{kDa}$ and other about $25 \mathrm{kDa}$ indicating high concentration of immunoglobulin with some other protein bands in $12.5 \%$ SDS PAGE. The concentration of the precipitated immunoglobulin was determined by spectrophotometer as $2 \mathrm{mg} / \mathrm{ml}$.

Isolation and purification of mouse immunoglobulin G using Protein A agarose

The purity of the Protein A agarose purified $\mathrm{IgG}$ was analyzed for purity in $12.5 \%$
SDSPAGE (Fig. 1) and also in $10 \%$ native PAGE. The fractions were free from any contaminant proteins and contained only IgG of $150 \mathrm{kDa}$ (Fig. 2). The concentration of the purified immunoglobulin was determined spectrophotometrically as $1.25 \mathrm{mg} / \mathrm{ml}$ against buffer B as blank.

\section{Digestion of mouse IgG with preactivated papain}

The concentration of the preactivated papain was determined spectrophotometrically as $1.13 \mathrm{mg} / \mathrm{ml}$ and used for digestion. The mouse IgG after digestion with the activated papain was checked in SDSPAGE (12.5\%) under non reducing conditions and the gel revealed three detectable bands representing $110 \mathrm{kDa}$ undigested IgG, $50 \mathrm{kDa} \mathrm{Fab}$ and $27 \mathrm{kDa} F \mathrm{Fc}$ fragment which confirmed the digestion steps (Fig. 3).

\section{Purification of Fc fragment in protein A agarose}

The eluted fractions were checked for the presence of $\mathrm{Fc}$ fragment in $12.5 \%$ nonreducing SDS PAGE revealed single pure band of about $27 \mathrm{kDa}$ representing $\mathrm{Fc}$ fragment (Fig. 4). The concentration of protein A agarose purified Fc fragment was determined spectrophotometrically as 400 $\mu \mathrm{g} / \mathrm{ml}$ of fraction at $280 \mathrm{~nm}$ against buffer Bas blank.

\section{Purification of recombinant outer membrane protein 28 (rOMP 28) of brucella melitensis}

The eluted fractions of Ni-NTA column were checked in $12.5 \%$ SDS PAGE and28 $\mathrm{kDa}$ $r \mathrm{OMP}$ was noticed in different eluates. The eluates containing high concentration of $r$ OMP 28 were pooled and dialyzed (Fig. 5). The concentration of the purified rOMP28 after pooling was determined as $1 \mathrm{mg} / \mathrm{ml}$ by 
Lowry method as well as by UV spectrophotometry.

\section{Confirmation of conjugate formation}

The $\mathrm{IgG} \quad \mathrm{Fc}$ and $r \mathrm{OMP} 28$ conjugate formation was confirmed in $12.5 \%$ SDSPAGE which revealed one band in the range of 50 and $55 \mathrm{kDa}$ anda nother band in the range of 25 and $30 \mathrm{kDa}$ which is suggestive of unconjugated $\mathrm{Fc}$ and/or $r$ OMP28 proteins (Fig. 6). The concentration of the conjugate was determined as $310 \mu \mathrm{g} / \mathrm{ml}$ in UV spectrophotometer.

\section{Evaluation of humoral immune response}

\section{Indirect ELISA}

The humoral immune response against $r \mathrm{OMP}$ 28 specific $\operatorname{IgG}$ isotypes was measured by indirect ELISA. Thelevel of the different subclasses of antibodies in the test serum at dilution of 1:100 was expressed as absorbance (OD492) of the color complex developed in the assay (indirect ELISA).

\section{Isotype profile}

It is known that different vaccination approaches and the route of antigen delivery can affect the antibody isotype and $\mathrm{T}$ helper cell type in an immune response. IgG2a is produced as a consequence of Th1 subset lymphocyte activation, whereas $\mathrm{Th} 2$ subset lymphocyte activation enhances IgG1 and suppresses IgG2a (Abbas et al., 1996; Mossman and Coffman 1989).

The total IgG antibody level started increasing significantly from day 7 post immunization till day 21 post immunization in all the groups except those groups which received PBS and S19 strain. On day 7 and 14 post immunization, animals from group5 showed highest responses which were maintained till day 21 , followed by group 2 , and 4. Significant increase in the group 3 animals could be observed on day 21 after the administration of first booster dose on day 14 . However, the IgG antibody response started decreasing on day 28 post immunization. Kinetics of antibody response revealed that mice immunized with $r$ OMP 28 conjugated with $\mathrm{Fc}$ portion showed less significant difference in antibody production in comparison to other immunized groups. The vaccine strain immunized mice formed less significant IgG antibodies against $r$ OMP 28 compared to all other groups (Fig.7).

\section{IgG1 response}

The IgG1 antibody response against $r$ OMP 28 were found to be highly significant on day 14,21 and 28 in between groups on day 7. The antigen specific $\operatorname{IgG} 1$ antibody levels were increasing from day 7 to day 28 . The highest response was found in animals from group 3 on 28 days post immunization followed by group 6 and 2 . The vaccine strain immunized mice produced less significant $\mathrm{IgG} 1$ antibodies against $r$ OMP 28 compared amongst all other groups (Fig. 8).

\section{IgG2a response}

The IgG2a antibody response against $r$ OMP28 were found to be increasing right from day 7 till 28 days post immunization in all the groups except group7.The highest response was observed on group 5followed by group 2,4 and 3.The vaccine strain immunized mice produced less significant IgG2a antibodies against $r$ OMP 28 compared amongst all other groups (Fig. 9).

\section{IgG2b response}

The IgG2b antibody response against $r \mathrm{OMP}$ 28 was not found to be significant $(\mathrm{P}<0.101)$ on day 7 post immunization but were highly 
significant on all other days $(\mathrm{P}<0.000)$ between groups. Significant increase in the level of IgG2b antibody was observed till day 21 post immunization whereas, a mixed type of response was observed among groups on day 28. The vaccine strain immunized mice produced less significant $\mathrm{IgG} 2 \mathrm{a}$ antibodies against rOMP 28 compared amongst all other groups (Fig. 10).

\section{Determination of antigen specific antibodies by western blotting}

To confirm the presence of specific antibodies against rOMP 28, the sera from different group of animals were analyzed by western blotting. All the group of animals reacted almost similarly to rOMP 28 except the PBS which has not reacted at all. The S19 group of animals showed less reactivity to rOMP 28 when compared to other groups (Fig. 11).

\section{Evaluation of cell mediated immune response}

\section{Lymphocyte proliferation assay}

The stimulation indices of the stimulated splenocytes ranged between. $0.87 \pm 0.01$ to 1.5 \pm 0.00 . The blastogenic responses were found to be higher on day 30 post immunization which was reduced after 40 days post immunization. On day 30 group 2 mice exhibited highest blastogenic response which is followed by group 5, 4, 3, 6 and control. Proliferation of splenocytes after second week of last immunization was reduced. Splenocytes from all groups of mice including PBS control showed similar proliferative responses upon stimulation with Con A (Fig. 12).

\section{Nitric oxide estimation}

The macrophage function in terms of production of nitric oxide was assessed by estimating the level of nitrite in the splenocyte culture supernatant collected after $96 \mathrm{hrs}$ of incubation which was stimulated with $r \mathrm{OMP}$ 28 on days 30 and 45 of primary immunization. The nitrite concentration ranged from $5 \mu \mathrm{M}$ to $22 \mu \mathrm{M}$. Among all the groups, group6 (vaccine strain S19) showed highest level of nitrite concentration on day 30 as well as on day 45 post immunization. The remaining groups also showed variable levels of nitrite levels on different days (Fig. 13).

\section{Protection Study}

Protection assay in the form of bacterial clearance was carried out after 30 days of giving challenge infection with virulent $B$. abortus 544 to the vaccinated and control mice. Challenge dose was fixed as $1 \times 10^{5}$ organisms per animal intra peritoneally. The level of infection/clearance in each group was evaluated by determining the colony forming unit(CFU) of bacteria in the spleen. Three mice from each group were sacrificed to determine the protection level. The results indicated group6, conferred highest protection with1.05 log unit of protection followed by group 5 with $0.04 \mathrm{log}$ unit of protection. However, the groups immunized with $r \mathrm{OMP}$ 28 and conjugate vaccine conferred very less protection (Table 2 and Fig. 14).

\section{Discussion}

Brucellosis is an economically important zoonotic disease caused by a facultative intracellular bacterium that causes abortion and infertility in cattle and undulant fever in humans.(Young et al., 1985)1 Because of its serious economic and medical consequences, efforts have been made to control this important disease through vaccination with live attenuated $B$. abortus strain 19 and killed strain 45/20 in cattle. Although these vaccines have been found effective against brucellosis, 
they do have some disadvantages, such as the ability to cause disease in humans, the possibility of causing abortion when administered to pregnant cattle, and the diagnostic difficulty of distinguishing field infections from vaccinated animals (Baldi et al., 1996). A vaccine that will be noninfectious and effective in stimulating a broad protective immune response is needed to control brucellosis. With the advent of genetic engineering techniques, it is now possible to generate noninfectious vaccines like subunit and DNA vaccines for economically important disease like brucellosis. Brucella protein named $\mathrm{CP} 28$, BP26, or Omp28 has been identified as an immunodominant antigen in infected cattle, sheep, goats, and humans (Gupta et al., 2010). In this study, the recombinant outer membrane protein 28 ( $r \mathrm{OMP} 28$ ) has been investigated as vaccine candidate.

The state of immunity against a particular microorganism should be established in the host in order to get rid of infection. Several factors play rolein inducing an effective immune response viz, molecular weight, number of epitopes, conformation, degradability, the way in which the immune cells recognize the antigen etc., and many of these components fail to induce a desirable protective immune response by itself. In such cases, it needs to be adjuvanted or targeted to the immune cells capable of inducing a protective response. One such approach is investigated in this research through $\mathrm{Fc}$ receptor mediated antigen delivery to induce potent immunity by targeting the antigen $r$ OMP 28 subunit vaccine to immune effector cells.

Receptors for Fc portion of IgG $(\mathrm{Fc} \gamma \mathrm{R})$ play an essential role in antibody-dependent immune responses (Ravetch and Kinett, 1991). These Fc receptors can recognize the immune complex made of $\mathrm{IgG}$ and an antigen and are involved in receptor mediated phagocytosis and able to present antigens to $\mathrm{T}$ cells, secretion of reactive oxygen intermediates and lysosomal hydroxylases and ultimately mediates antibody dependent cell mediated cytotoxicity (ADCC). The dendritic cells possessing FcRs are involved in cross presentation. These receptors transmit either activating or inhibitory signals via immune receptor tyrosine-based activation motifs (ITAMs) or immune receptor tyrosine-based inhibitory motifs (ITIMs), respectively (Ravetch and Lanier 2000)provide a link between humoral and cell mediated response by targeting immune complexes to effector cells.

Serum was used as a source of immunoglobulin since it harvests high concentration and considering the ease of collection. Serum pooled from 40 mice yielded large quantities of immunoglobulin as evidenced spectrophotometrically. Since the study requires only IgG, Protein A agarose (Sigma) was used for the isolation of pure IgG. The Protein A bound the IgG isotype alone and leaving all other isotypes in the elute. The purified IgG fractions obtained from eluting the Protein A agarose revealed only two bands at $55 \mathrm{kDa}$ and another around $25 \mathrm{kDa}$ indicating the heavy and light chains of $\mathrm{IgG}$ in SDS-PAGE which was in accordance with Ey et al., (1978) and Singh et al., (2008).

The purified immunoglobulin was used to obtain Fc fragment by subjecting to fragmentation with preactivated papain. Digestion of the mouse $\mathrm{IgG}$ yielded undigested $\mathrm{IgG}, \mathrm{Fab}$ and $\mathrm{Fc}$ fragments $(110,55$ and $27 \mathrm{kDa})$ along with one more band which represents papain $(24 \mathrm{kDa})$ in native PAGE(Singh et al., 2008; Coleman and Mahler 2003). The Fc fragment purified in the Protein A agarose column revealed a single band of $\mathrm{Fc}$ fragment of about $27 \mathrm{kDa}$ 
demonstrating the purity of the preparation. The efficiency of conjugation assured in SDS PAGE revealing a high molecular weight band around $55 \mathrm{kDa}$ enable us to proceed for immunization.

The present study was conceptualized with the hypothesis that receptor mediated antigen delivery will trigger the immune response against $r$ OMP 28. The humoral immune response kinetics was studied after immunization in all the groups up to 28 days post immunization. The IgG response was found to be on increasing till day 21 and started decreasing on day 28 indicative of the recombinant protein'sability to induce humoral immune response which further increased upon booster immunization. The total IgG response throughout the study period remained highest in the group immunized with rOMP 28 alone and Fc+rOMP 28 (unconjugated) suggesting that unaltered proteins could be a better antigen than conjugated proteins. The lesser total IgG response in conjugate group throughout the study in comparison to rOMP 28 alone group could be attributed to the irreversible loss of Fc receptors from the macrophage plasma membrane (Mellman et al., 1983)or can be ascribed to the alterations in the immune conjugate due to conjugation which might have resulted in a generation of different/novel immunogenic peptides to induce the immune response.

The IgG1 profile of the immunized groups showed increasing trends from day 7 and further increase could be appreciated after the two boosters on day 14 and 21 with the highest response on day28. However, on day 28 the conjugate group showed highest level IgG1 response suggestive of activation of Th2 subset of lymphocytes (Abbas et al., 1996; Mossman and Coffman, 1983). The magnitude of $\mathrm{IgG} 2 \mathrm{a}$ response indicative of Th1 subset of lymphocyte activation was similar to that of total $\mathrm{IgG}$ response with unaltered rOMP 28 showing the maximum antibody response. The antibody response of the vaccine strain (group 6) mice to the $r \mathrm{OMP}$ 28 was the least when compared to the other groups in indirect ELISA as well as in western blotting. The current live attenuated vaccines against animal brucellosis induce high titer antibodies against the $\mathrm{O}$ polysaccharide of the LPS. Furthermore, the immune gold labeling of OMP 28 on the $16 \mathrm{M}$ smooth strain of $B$. melitensis detected by electron microscope was specific but at a low level, suggesting that OMP 28 is not highly exposed on the surface of these cells. The OMP 28 of B. melitensis was not recognized by sera obtained from B. abortus 2308 infected cattle or swine naturally infected with B. suis (Blasco and Diaz 1993). The vaccine strain B.abortus $S 19$ developed from virulent $B$. abortus strain may have a different type of OMP due to spontaneous mutation which was not detected by the $\mathrm{r}$ OMP 28 of Brucella abortus 544 strain(Lindler et al., 1996).

In a study to evaluate BP26/ OMP28 in serological diagnosis of B.melitensis infection in sheep, the absorbance values in indirect ELISA did not reach those observed in indirect ELISA using purified $\mathrm{O}$ polysaccharide as an antigen. The antibody response to BP26/OMP 28 was delayed and much weaker than to $\mathrm{O}$ polysaccharide. Hence, the weak response to OMP 28 suggests that it can be used to differentiate infected and vaccinated animals (Cloeckert et al., 2001)

Cell mediated immunity plays an important role in the protection against intracellular organisms like Brucella. The cell mediated immunity against $r \mathrm{OMP} 28$ in mice evaluated by in vitro stimulation of lymphocytes with rOMP 28 induced highest proliferation in group 2 which received $r$ OMP 28 alone on 30 days post immunization. 
Table.1 Immunization schedule in mice

\begin{tabular}{|l|c|c|c|}
\hline Groups & Inoculum & Dose/mice & $\begin{array}{c}\text { Route of } \\
\text { Immunization }\end{array}$ \\
\hline $\mathbf{1 .}$ & PBS & $0.1 \mathrm{ml}$ & $\mathrm{S} / \mathrm{C}$ \\
\hline $\mathbf{2 .}$ & $r$ OMP28 alone & $50 \mu \mathrm{g}$ & $\mathrm{S} / \mathrm{C}$ \\
\hline $\mathbf{3 .}$ & Conjugate of $r$ OMP28 with Fc fragment & $100 \mu \mathrm{g}$ & $\mathrm{S} / \mathrm{C}$ \\
\hline $\mathbf{4 .}$ & Glutaraldehyde treated $r$ OMP 28 & $50 \mu \mathrm{g}$ & $\mathrm{S} / \mathrm{C}$ \\
\hline $\mathbf{5 .}$ & Fc $+r$ OMP 28 & $50 \mu \mathrm{g}+50 \mu \mathrm{g}$ & $\mathrm{S} / \mathrm{C}$ \\
\hline 6. & Brucella abortus S19 (Vaccine strain) & $1 \times 10^{5} \mathrm{CFU}$ & $\mathrm{I} / \mathrm{P}$ \\
\hline
\end{tabular}

Table.2 Table representing CFU of B.abortus 544 in spleen after challenge in different immunized groups

\begin{tabular}{|c|l|c|c|}
\hline $\begin{array}{l}\text { Experimental } \\
\text { Groups }\end{array}$ & $\begin{array}{l}\text { No. } \\
\text { B.abortus } \\
\text { 544 in spleen }\end{array}$ & $\begin{array}{l}\log _{10} \text { CFU of } \\
\text { B.abortus in spleen } \\
\text { Mean } \pm \text { SE }\end{array}$ & $\begin{array}{l}\text { Log unit of } \\
\text { protection }\end{array}$ \\
\hline I & $3.87 \times 10^{5}$ & $5.55 \pm 0.09$ & 0 \\
\hline II & $1.23 \times 10^{6}$ & $6.08 \pm 0.05$ & -0.50 \\
\hline III & $4.37 \times 10^{5}$ & $5.6 \pm 0.02$ & -0.05 \\
\hline IV & $3.87 \times 10^{5}$ & $5.58 \pm 0.04$ & 0 \\
\hline V & $3.5 \times 10^{5}$ & $5.53 \pm 0.04$ & 0.04 \\
\hline VI & $3.37 \times 10^{4}$ & $4.51 \pm 0.07$ & 1.05 \\
\hline
\end{tabular}

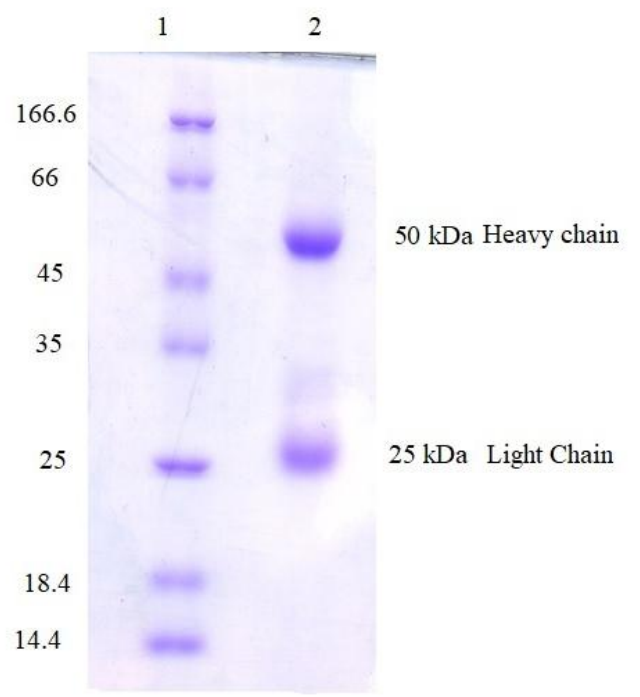

Fig. 1 Protein A purified mouse IgG in 12.5\% SDS PAGE

Lane 1: Protein Molecular Weight Marker Lane 2: Purified IgG fragments

Fig.1 Protein A purified Mice IgG in $12.5 \%$ SDS PAGE 


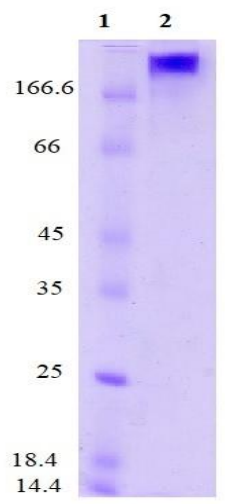

Fig.2 10\% Native PAGE showing Protein A purified mouse IgG Lane 1: Protein Molecular weight marker (kDa)

Lane 2: Protein A purified Mouse IgG (150 kDa)

Fig.2 Protein A purified mouse IgG in 10\% native PAGE

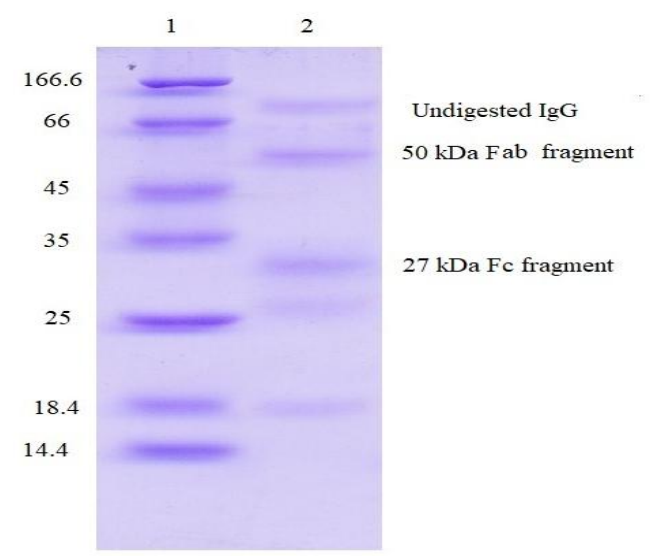

Fig.3 Papain digested mice IgG in 12.5\% Native PAGE

Lane 1: Protein molecular weight marker

Fig.3 Papain digested mice IgG in $12.5 \%$ Native PAGE

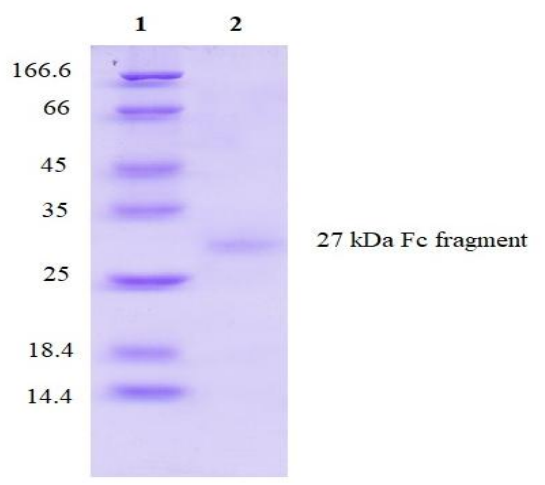

Fig.4 Protein A purified Fc fragment of mouse IgG

Lane1: Protein Molecular Weight Marker

Lane2: Purified Fc fragment of $\operatorname{IgG}(27 \mathrm{kDa})$

Fig.4 Protein A purified Fc fragment of IgG 


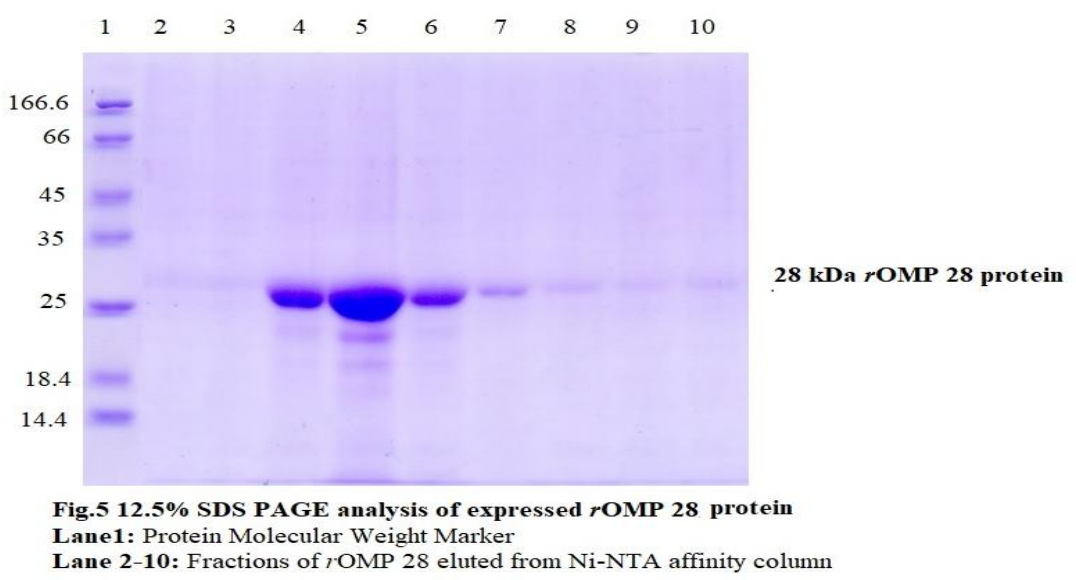

Fig.5 12.5\% SDS PAGE analysis of expressed $r$ OMP 28 protein

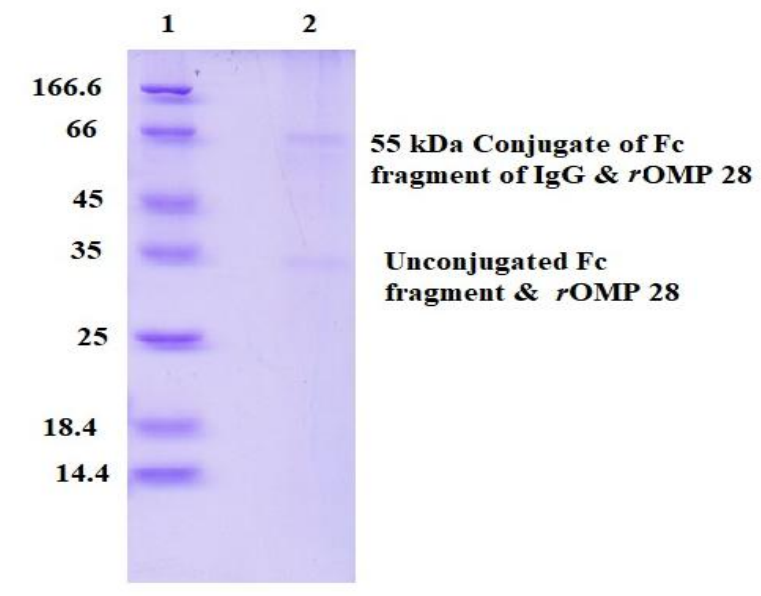

Fig.6 Conjugate prepared from Fc fragment of IgG and rOMP 28

Lane 1: Protein Molecular Weight Marker

Lane 2: Conjugate of Fc fragment of $\mathrm{IgG}$ and $r \mathrm{OMP} 28(55 \mathrm{kDa})$

Fig.6 Conjugate of Fc fragment of $\mathrm{IgG}$ and $r \mathrm{OMP} 28$

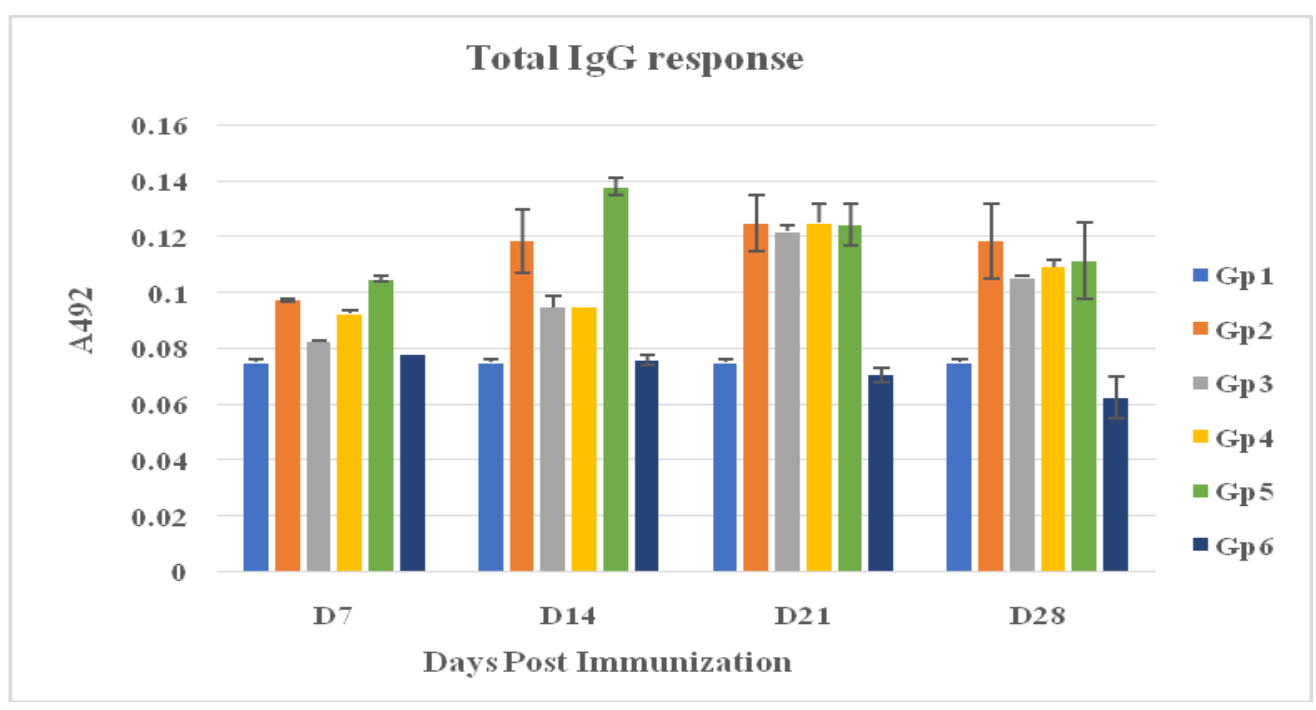

Fig.7 Total IgG response to immunization with $r$ OMP 28 in different groups 


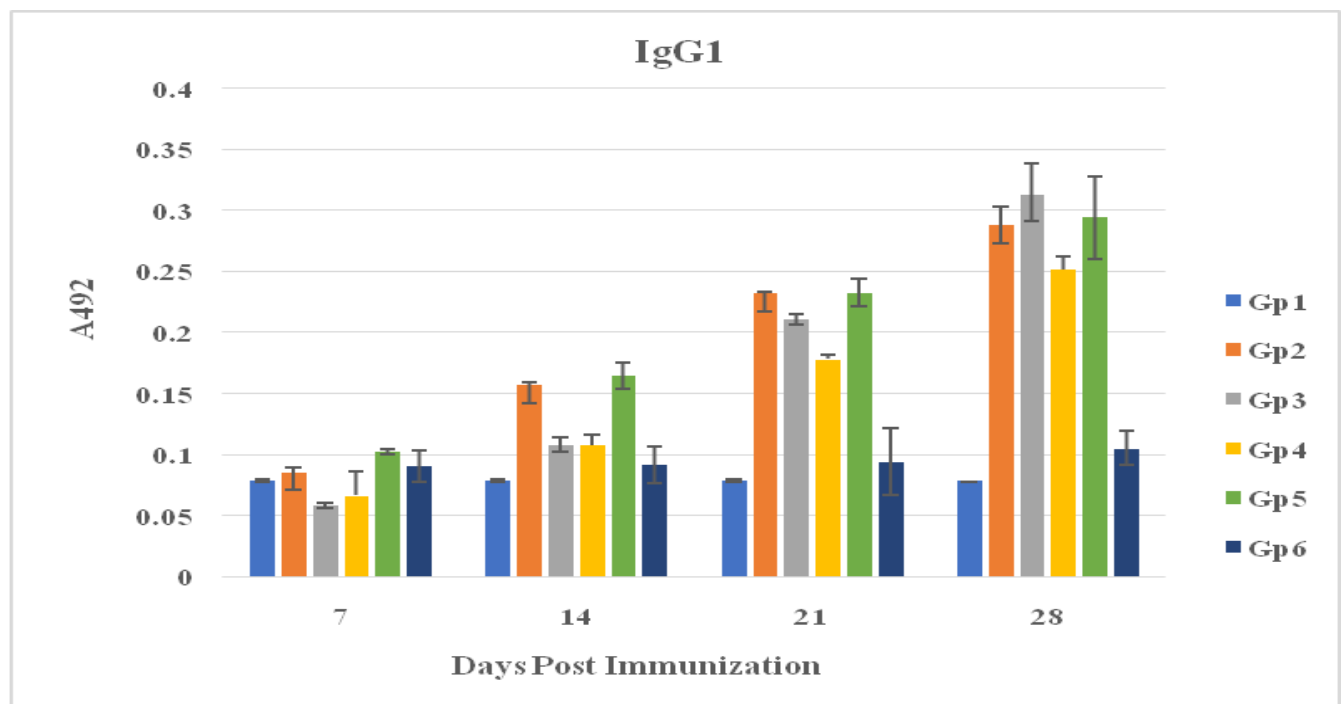

Fig.8 IgG1 response to immunization withrOMP 28 in different groups

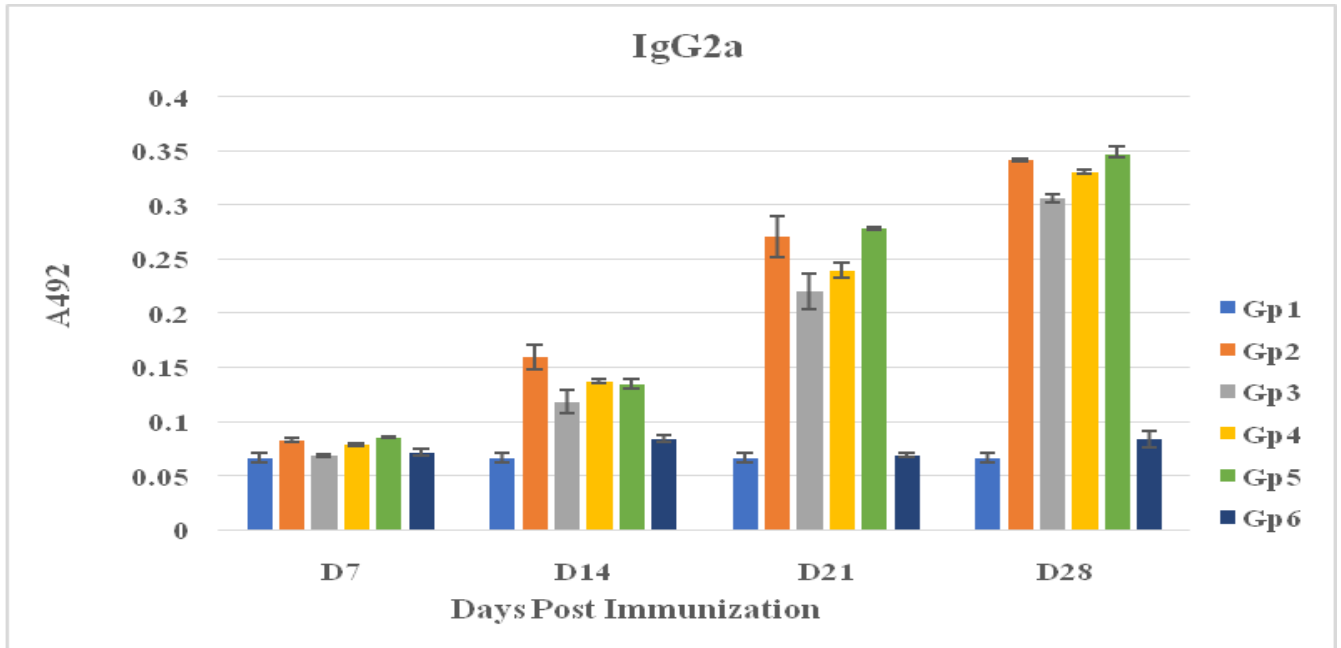

Fig.9 IgG2a response to immunization with $r \mathrm{OMP} 28$ in different groups

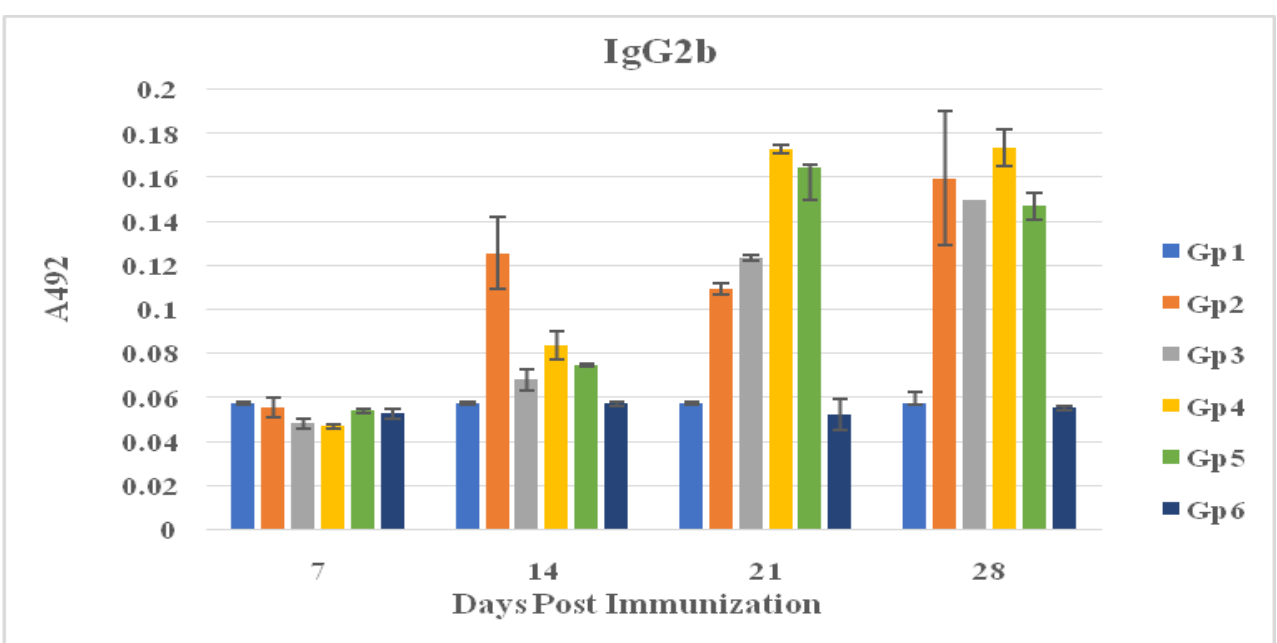

Fig.10 IgG2b response to immunization with $r$ OMP 28 in different groups 


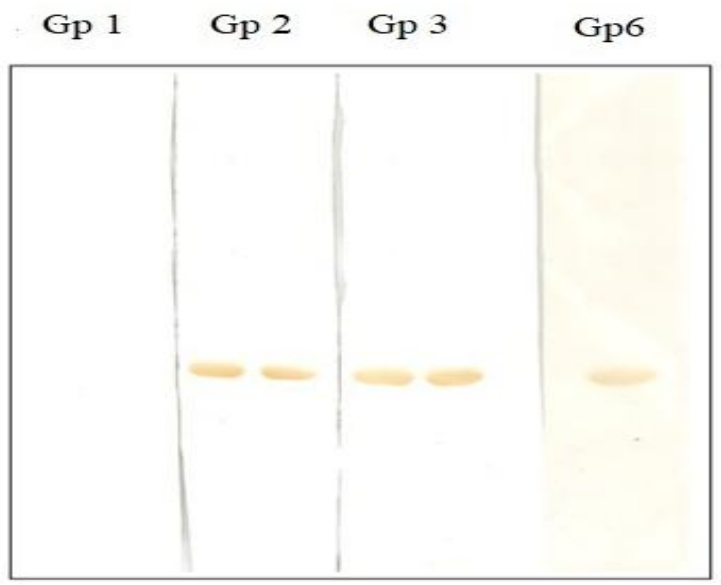

Fig. 11 Western blot analysis of Group $1,2,3$ \& 6 against $r$ OMP 28

Fig.11 Western blot analysis of immunized groups against $r \mathrm{OMP} 28$

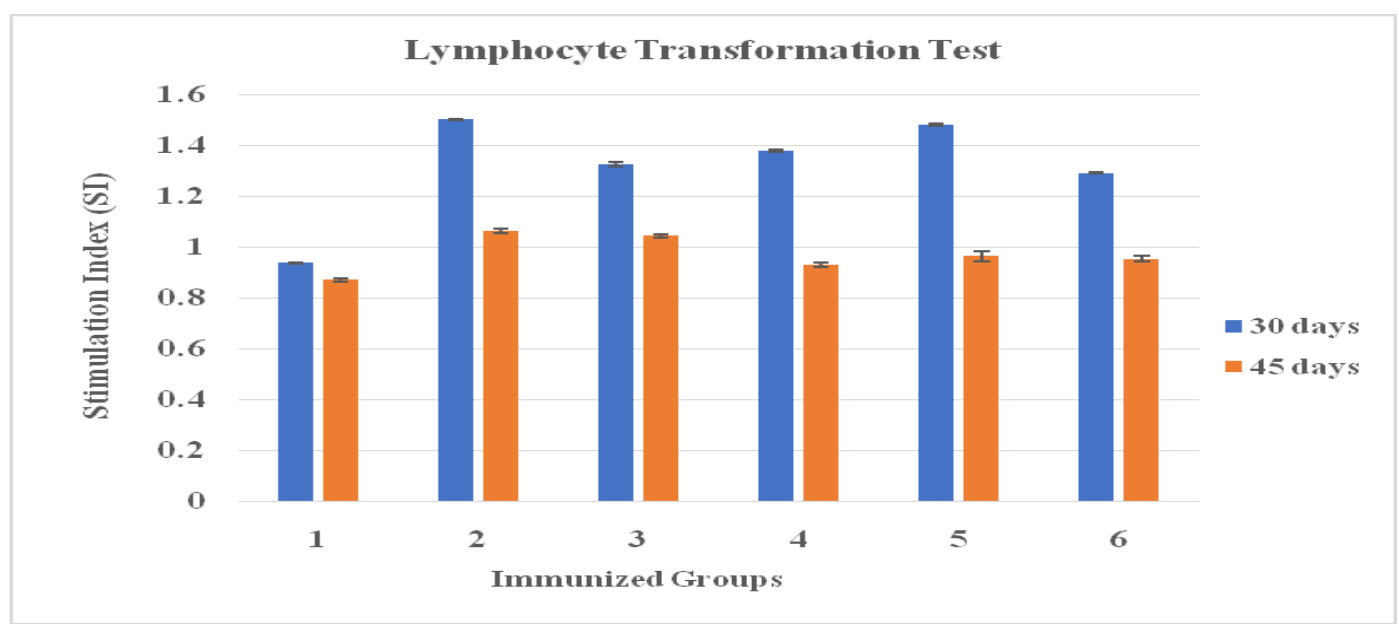

Fig.12 Lymphocyte transformation assay of mice immunized with rOMP 28

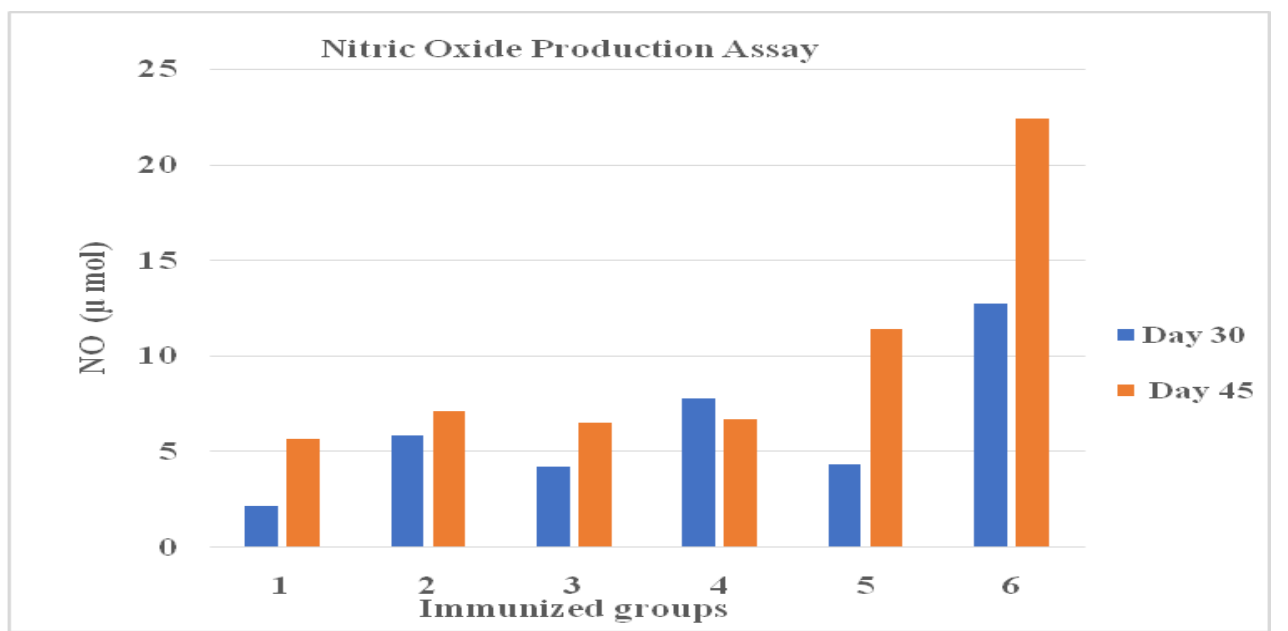

Fig.13 Nitric oxide production in $96 \mathrm{hrs}$ culture supernatant $\left(\mu \mathrm{mol} / 2 \times 10^{6}\right.$ cells $)$ on different days from the splenocytes of immunized mice 


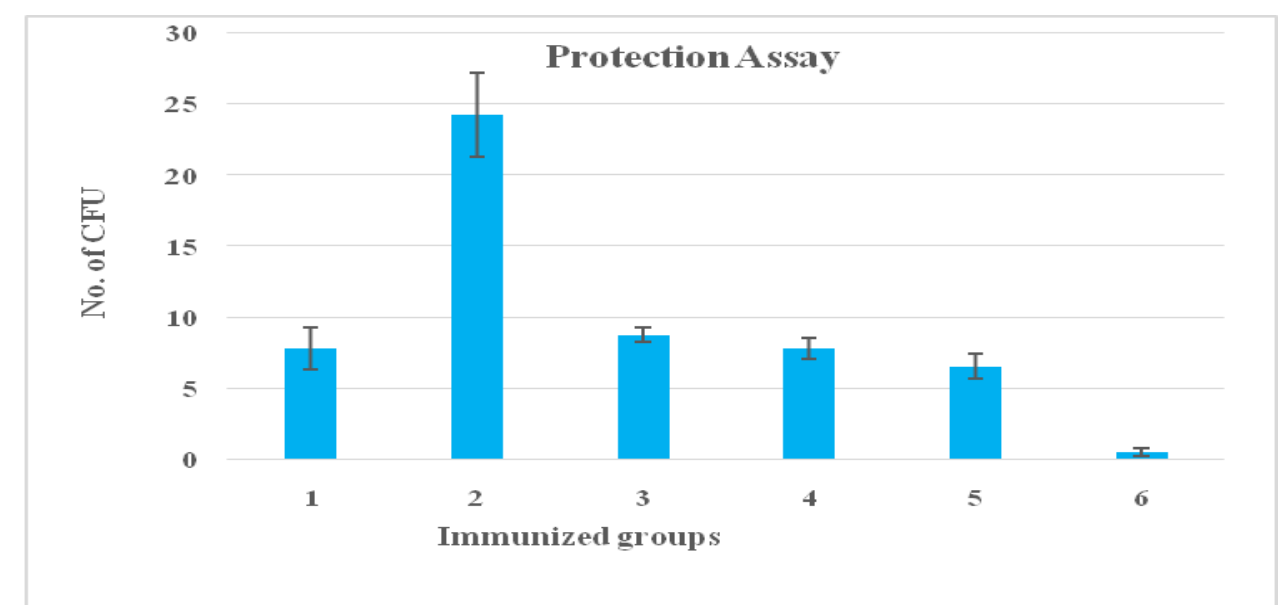

Fig.14 Diagram representing CFU of B.abortus 544 in spleen after challenge in different immunized groups

However, 45 days after immunization, the proliferation started decreasing in all the groups suggestive of weak cell mediated immunity induced by subunit vaccine $r \mathrm{OMP}$ 28. Nitricoxide synthesized by the inducible nitric oxide synthase of macrophages is a predominant microbicidal agent. The nitric oxide production was highest in the S19 group both on 30- and 45-days post immunization which may be the reason for the highest level of protection conferred by S19 group after challenge. The low level of nitric oxide in rest of the groups in the present study clearly emphasizes its role in conferring protection against the intracellular bacteria like Brucella. The present study discloses though the antibody response in indirect ELISA in the B. abortusS19 group is lowest among all the groups using rOMP 28 as antigen, the protection conferred by the S19 vaccine was found to be highest.

In conclusion, Brucella being an intracellular pathogen needs to be cleared out by the cell mediated immune system and innate immune cells like macrophages. Hence, it may be inferred as the rOMP 28 which constitutes a little part of the organism alone may not be able to provide a full protection against the infection. This was evident in the results of protection study after challenge.
On the other hand, since the live vaccine is composed of lot many components like OMP, LPS, etc. these fractions of the organism might have a role in conferring protective immune response.

Overall, the lower immune response of both humoral and cell mediated in the conjugate group can be attributed to following factors. First of all, two types of Fc $\gamma$ Rs are expressed by the immune cells that are activating which include Fc $\gamma$ RI and Fc $\gamma$ RIII and the inhibitory Fc $\gamma$ RII. There are reports to support this view that there is an augmented humoral response and anaphylactic responses by Fc $\gamma$ RII deficient mice (Toshiyuki et al., 1996; Nimmerjahn and Ravetch, 2005). The uptake of antigens via distinct extracellular and intracellular Fc $\gamma R s$ influences antigen presentation, and determines whether the antigen is degraded or presented and the type of epitopes that are presented (Guilliams et $a l .$, 2014). There is also evidence that soluble forms of Fc $\gamma$ Rs are released by the Langerhan cells of mice to inhibit Fc $\gamma \mathrm{R}$ mediated antigen presentation (Esposito- Farese et al., 1995). Apart from the Fc $\gamma \mathrm{R}$ mediated antigen uptake, the fate of the Fc receptors after endocytosis was different. Studies suggests that receptor mediated phagocytosis led to the selective and irreversible removal of $\mathrm{Fc}$ receptors $(>50 \%)$ 
from macrophage plasma membrane (Mellman et al., 1983). It is also notable that due to the high circulating levels of $\mathrm{IgG}$ in mouse serum $(-6 \mathrm{mg} / \mathrm{mL})$, it is expected that the binding sites of high-affinity $\mathrm{IgG}$ receptors are constitutively saturated by $\mathrm{IgG}$ in vivo, at least on circulating cells. The ability of FcRs to induce biological functions following interaction with immunoglobulins (i.e. activation, inhibition, internalization, routing, transport) depend on the molecular state of the ligands, whether monomeric, present in an immune complex, or opsonizing cells, viruses, or bacteria. Moreover, binding of monomeric IgG by mouse FcyR I and $\mathrm{Fc} \gamma \mathrm{R}$ IV has not been reported to lead to biological functions whereas multimeric immune globulins, however, trigger activating FcRs to mediate intracellular signaling leading to a diversity of cellular responses including phagocytosis, cell differentiation, cell migration, degranulation, secretion of mediators, antibody-dependent cellular cytotoxicity (Bruhns and Johnson, 2015).

\section{Acknowledgements}

The authors are thankful to the Director, Indian Veterinary Research Institute, Bareilly, India, ICAR for providing necessary funding and facilities to carry out this research work.

\section{References}

Abbas AK, Murphy KM, Sher A (1996). Functional diversity of helper $\mathrm{T}$ lymphocytes. Nature 383:787-93.

Alton G, Jones. G, Lois M, Pietz DE (1975). Laboratory techniques in brucellosis. 2nd edn. World Health Organization \& Food and Agriculture Organization of the United Nations.

Baldi PC, Giambartolomei GH, Goldbaum FA, Abdo'n LF, Velikovsky CA, Kittelberger R, Fossati CA (1996). Humoral immune response against lipopolysaccharide and cytoplasmic proteins of Brucella abortus in cattle vaccinated with B. abortus $S 19$ or experimentally infected with Yersinia enterocolitica serotype O:9. Clin. Diagn. Lab. Immunol 3: 472- 476.

Baron MH. and Baltimore D (1982). Antibodies against the chemically synthesized genome-linked protein of polio virus react with native virus specific proteins. Cell28:395-404.

Blasco JM and Diaz R (1993). Brucella melitensis Rev-1 vaccine as a cause of human brucellosis. Lancet 342:805

Bruhns P and Jönsson F. Mouse and human FcR effector functions (2015). Immunol. Rev. Nov: 268(1):25-51. doi: 10.1111/imr.12350.

Cloeckaert A, Baucheron S, Vizcaino N, Zygmunt MS (2001). Use of recombinant BP26 protein in serological diagnosis of Brucella melitensis infection in sheep. Clin Diagn. Lab. Immunol 8:772-5.

Coleman L, Mahler SM (2003). Purification of Fab fragments from a monoclonal antibody papain digest by Gradiflow electrophoresis. Protein expression and purification. 32(2): 246-251.

Debbarh HS, Cloeckaert A, Bezard G, DubrayG, Zygmunt MS (1996). Enzyme linked immunosorbent assay with partially purified cytosoluble 28-kilodalton protein for serological differentiation between Brucella melitensis infected and $B$. melitensis Rev.1 vaccinated sheep. Clin. Diagn. Lab. Immunol 3:305-8.

Esposito-Farese ME, Sautes C, de la Salle H, Latour S, Bieber $\mathrm{T}$, de La Salle $\mathrm{C}$, Teillaud, J. L. (1995). Membrane and soluble Fc gamma RII/III modulate the antigen-presenting capacity of murine dendritic epidermal Langerhans cells for IgG-complexed antigens. J. Immunol 155(4): 1725-1736.

Ey, PL, Prowsse, SJ, Jerkin CR (1978). Isolation of pure IgG1, IgG2a, IgG2b, immunoglobulins from mouse serum using protein A Sepharose. Immunochem 15: 429-436.

Fridman WH, Bonnerot C, Daeron M, Amigorena S, Teillaud, Sautes C (1992). Structural bases of Fc $\gamma$ receptor function. Immunol. Rev.; 125: 49-76.

Guilliams M, Bruhns P, Saeys Y, Hammad H, 
Lambrecht BN (2014). The function of Fc gamma receptors in dendritic cells and macrophages. Nat. Rev. Immunol 14: 94 108.

Gupta V K, Kumari R, Vohra J, Singh, SV, Vihan, VS (2010). Comparative evaluation of recombinant BP26 protein for serological diagnosis of Brucella melitensis infection in goats. Small rum. res 93(2-3):119-125.

Laemmli UK (1970). Cleavage Of Structural Proteins During The Assembly Of The Head Of Bacteriophage T4. nature.; 227. 5259: 680-685.

Lindler LE, Hadfield TL, Tall BD, Snellings NJ, Rubins FA, Van De Verg LL, Warren RL (1996). Cloning of Brucella melitensis group 3 antigen gene encoding Omp28, a protein recognized by the humoral immune response during human brucellosis. Infect. Immun 67:2490-9.

Lowry OH, Rosbrough NJ, Farr, Randall RJ (1951). Protein measurement with the folin phenol reagent. J. Biol. Chem.193 AL (1): 265-275.

Mellman IS, Plutner H, Steinman RM, Unkeless JC, Cohn ZA (1983). Internalization and degradation of macrophage Fc receptors during receptor-mediated phagocytosis. J. Cell Biol 96(3): 887-895.

Mosman TR, Coffman RL (1989). Heterogeneity of cytokine secretion patterns and functions of helper $\mathrm{T}$ cells. Adv. Immunol.; 46:111- 47.

Mosmann T (1983). Rapid colorimetric assay for cellular growth and survival: application to proliferation and cytotoxicity assays. J. Immunol. Methods 65(1-2): 55-63.

Nimmerjahn F, Ravetch JV (2005). Divergent immunoglobulin $\mathrm{g}$ subclass activity through selective $\mathrm{Fc}$ receptor binding. Science 310: 1510-1512.

Parham P, Androlewicz MJ, Brodsky FM, Holmes NJ, Ways JP (1982). Monoclonal antibodies: purification, fragmentation and application to structural and functional studies of class I MHC antigen. J. Immunol. Methods, 53: 133-147.

Qiu WQ, de Bruin D, Brownstein BH, Pearse R, Ravetch JV (1990). Organization of the human and mouse low-affinity Fc gamma $\mathrm{R}$ genes: duplication and recombination. Science, 248:732-5.

Ravetch JV, Kinet JP (1991). Fc receptors. Ann. Rev. Immunol., 9:457-92.

Ravetch JV, Lanier LL (2000). Immune inhibitory receptors. Science 290:84-9.

Santos JM, Verstreate DR, Perera VY, Winter AJ (1984). Outer membrane proteins from rough strains of four Brucella species. Infect. Immun 46: 188-194.

Singh M, Saini D, Ram GC, Goswami TK (2008). Single step chromatographic and enzymatic technique for purification and digestion of mouse IgG. Journal of Immunol. Immunopathol 10(1): 60-64.

Toshiyuki T, Ono M, Masaki H, Hitoshi O, Ravetch JV (1996). Augmented humoral and anaphylactic responses in Fc $\gamma$ RIIdeficient mice. Letters to Nature.

Towbin H, Staehelin T, Gordon J (1979). Electrophoretic transfer of proteins from poly-acrylamide gels to nitrocellulose sheets: Procedure and some applications. Proc. Natl. Acad. Sci76: 4350-4354.

Young EJ, Borchert M, Kretzer FL, Musher DM. (1985). Phagocytosis and killing of Brucella by human polymorphonuclear leukocytes. J. Infect Dis 151(4): 682-690.

\section{How to cite this article:}

Ramya Kalaivanan, Sankar Palanisamy, Tapas Kumar Goswami, Pallab Chaudhury and Ram, G. C. 2020. Immunological Evaluation of Fc Receptor Mediated Antigen Delivery of Brucella melitensis Recombinant Outer Membrane Protein 28 (Romp 28) in Mice. Int.J.Curr.Microbiol.App.Sci. 9(05): 2320-2338. doi: https://doi.org/10.20546/ijcmas.2020.905.265 